\title{
Mortality pattern of Murrah buffalo males in an organised herd
}

\author{
Pushp Raj Shivahre, A. K. Gupta, A. Panmei, M. Bhakat, V. Kumar, S. K. Dash, S. Dash and A. Upadhyay
}

Dairy Cattle Breeding Division, National Dairy Research Institute, Karnal - 132001, Haryana, India

Corresponding author: Pushp Raj Shivahre, email: drpr06@gmail.com

AKG: guptaak2009@gmail.com, AP: panmei.achun07@gmail.com, MB: bhakat.mukesh@gmail.com, VK: jaisvet@gmail.com, SKD: shaktikant07@gmail.com, SD: dr.soumya10@gmail.com, AU: upadhyay.arpan@gmail.com

Received: 11-03-2014, Revised: 19-04-2014, Accepted: 22-04-2014, Published online: 26-05-2014

doi: $10.14202 /$ vetworld.2014.356-359

How to cite this article: Shivahre PR, Gupta AK, Panmei A, Bhakat M, Kumar V, Dash SK, Dash S and Upadhyay A (2014) Mortality pattern of Murrah buffalo males in an organised herd, Veterinary World 7(5): 356-359.

\begin{abstract}
Aim: The present study was carried out to analyze mortality pattern in Murrah buffalo males in National Dairy Research Institute herd.

Materials and Methods: Records of 1029 Murrah buffalo males born during the period 1997-2012, at NDRI, Karnal, were analyzed to study mortality pattern in different age groups. The percent of animal disposed from the herd due to different reasons was calculated by proportion using descriptive statistics.

Results: The overall percent mortality in $0-1 \mathrm{~m}, 1-2 \mathrm{~m}, 2-3 \mathrm{~m}, 3-6 \mathrm{~m}, 6-18 \mathrm{~m}, 18 \mathrm{~m}-3 \mathrm{yr}$ and $>3$ year age groups were 17.49 , 5.99, $3.34,5.42,6.35,2.59$ and 3.93, respectively. The main cause of mortality in 0-1, 1-2, 2-3 and 6-18 $\mathrm{m}$ of age groups was respiratory problems $(6.61 \%, 1.79 \%, 1.06 \%$ and $1.97 \%$ respectively). Main causes of mortality in age group 3-6 months were general debility $(1.57 \%)$ followed by respiratory and digestive problems $(1.22 \%)$, miscellaneous $(0.87 \%)$, liver and urinary problems $(0.17 \%)$. Mortality could not reveal any consistent trend across different seasons and period of birth. General debility (1.29\%) followed by toxemia, liver problems and miscellaneous reasons were main causes of mortality in age group $18 \mathrm{~m}-3 \mathrm{yr}$ of age. In males above three years of age, general debility $(2.81 \%)$ followed by respiratory problems $(1.12 \%)$ were the main causes of mortality.
\end{abstract}

Conclusion: Intensive health care and management is required for young male buffalo calves especially in hot humid months of rainy season and cold inclement weather conditions in winter months to minimize mortality due to respiratory and digestive problems.

Keywords: age group, culling, male calves, mortality pattern, Murrah buffalo.

\section{Introduction}

The estimate of world buffalo population is approximately 185.29 million dispersed in 42 countries, out of which 97\% (179.75 million) are found only in Asia [1]. India has approximately 57\% (105.3 million) of the total world buffalo population. The water buffalo (Bubalus bubalis) contributes immensely to the agricultural economy through milk, meat, hides and draught power [2]. Share of buffalo milk occupies the highest position in Indian dairy industry, contributing about $56 \%$ of total milk (110 MT) produced by its varied population which is less than half that of the cattle population [3]. Population size of Murrah is 20.49 million which constitutes $19.45 \%$ of the total buffalo population of India [4]. Murrah buffalo is the most efficient milk producer and has better adaptability throughout India [5]. The breeding tract of Murrah buffalo breed comprises of Rohtak, Hisar and Jind districts of Haryana and Nabha and Patiala districts of Punjab in India [6].

Knowledge of disposal pattern of buffalo males from a herd is important because it aids in making more

Copyright: The authors. This article is an open access article licensed under the terms of the Creative Commons Attribution License (http://creativecommons.org/licenses/by/2.0) which permits unrestricted use, distribution and reproduction in any medium, provided the work is properly cited.

Veterinary World, EISSN: 2231-0916 accurate planning and successful execution of genetic improvement programmes. According to Afzal et al. [7] the mortality in cattle and buffalo calves ranged from $29.1 \%$ to $39.8 \%$. Martin and Wiggins [8] estimated that $20 \%$ calf mortality resulted in reduction of 38\% profit of a livestock farm. Dechow et al. [9] concluded that herd management system and selection of sire with high productive life evaluations was associated with lower mortality.

Reports of disposal pattern in cattle are available, but for Murrah breed of buffalo such information is scanty. Therefore, the present work was taken up to identify and summarize causes of mortality of Murrah Buffalo males from National Dairy Research Institute (NDRI) herd.

\section{Materials and Methods}

Data: Records on 1029 Murrah buffalo males born during the period 1997-2012, at NDRI, Karnal, were collected from Dairy Cattle Breeding Division, Cattle yard and Artificial Breeding Research Center. The collected data were analyzed to study mortality pattern in different age groups.

Data classification: Data were classified into four periods viz., P-1 (1997-2000), P-2 (2001-2004), P-3 (2005-2008), P-4 (2009-2012); four seasons viz., winter, 
Available at www.veterinaryworld.org/Vol.7/May-2014/17.pdf

Table-1: Overall percent mortality across different age groups of Murrah buffalo males

\begin{tabular}{|c|c|c|c|c|c|c|c|}
\hline EffectlAge group & 0-1 m & $1-2 \mathrm{~m}$ & $2-3 \mathrm{~m}$ & $3-6 \mathrm{~m}$ & $6-18 m$ & $18 \mathrm{~m}-3 \mathrm{yr}$ & $>3 \mathrm{yr}$ \\
\hline Overall & 17.49 & 5.99 & 3.34 & 5.42 & 6.35 & 2.59 & 3.93 \\
\hline \multicolumn{8}{|l|}{ Period } \\
\hline P1(1997-2000) & 17.82 & 9.41 & 4.40 & 7.91 & 6.42 & 6.02 & 15.00 \\
\hline P2(2001-2004) & 10.55 & 4.88 & 1.20 & 5.30 & 6.00 & 1.89 & 3.33 \\
\hline P3(2005-2008) & 13.49 & 2.97 & 2.89 & 2.65 & 6.03 & 0.00 & 0.00 \\
\hline P4(2009-2012) & 28.46 & 6.86 & 4.97 & 6.00 & 6.82 & 1.94 & 0.00 \\
\hline \multicolumn{8}{|l|}{ Season } \\
\hline S1 (Dec-Mar) & 22.19 & 4.52 & 4.79 & 7.05 & 5.34 & 2.35 & 4.76 \\
\hline S2 (Apr-Jun) & 16.30 & 6.19 & 1.90 & 6.59 & 15.09 & 5.56 & 8.33 \\
\hline S3 (Jul-Sep) & 14.40 & 5.88 & 3.21 & 4.97 & 5.39 & 2.59 & 2.99 \\
\hline S4 (Oct-Nov) & 17.01 & 8.07 & 2.70 & 3.47 & 4.72 & 1.39 & 2.22 \\
\hline
\end{tabular}

Table-2: Mortality pattern due to various problems in different age groups of Murrah buffalo males

\begin{tabular}{|c|c|c|c|c|c|c|c|c|c|c|c|}
\hline $\begin{array}{l}\text { Age } \\
\text { group }\end{array}$ & $\begin{array}{c}\text { No. } \\
\text { available }\end{array}$ & Total dead & $\begin{array}{l}\text { Respiratory } \\
\text { problem }\end{array}$ & $\begin{array}{l}\text { Digestive } \\
\text { problem }\end{array}$ & $\begin{array}{c}\text { Liver } \\
\text { problem }\end{array}$ & $\begin{array}{l}\text { General } \\
\text { Debility }\end{array}$ & $\begin{array}{l}\text { Cardio- } \\
\text { vascular }\end{array}$ & $\begin{array}{l}\text { Parasitic } \\
\text { diseases }\end{array}$ & Toxemia & Uro-genital & Misc. \\
\hline $0-1 \mathrm{~m}$ & 1029 & $180(17.49)$ & 6.61 & 5.05 & 0.87 & 1.75 & 0.49 & 0.1 & 0.97 & 0 & 1.65 \\
\hline $1-2 m$ & 784 & $47(5.99)$ & 1.79 & 1.79 & 0.13 & 1.02 & 0 & 0.13 & 0.77 & 0 & 0.38 \\
\hline $2-3 m$ & 659 & $22(3.34)$ & 1.06 & 0.46 & 0.3 & 0.76 & 0 & 0 & 0.3 & 0 & 0.61 \\
\hline $3-6 m$ & 572 & $31(5.42)$ & 1.22 & 1.22 & 0.17 & 1.57 & 0.17 & 0 & 0 & 0.17 & 0.87 \\
\hline $6-18 m$ & 457 & $29(6.35)$ & 1.97 & 0.66 & 1.09 & 1.09 & 0.22 & 0 & 0 & 0.66 & 0.66 \\
\hline $18 \mathrm{~m}-3 \mathrm{yrs}$ & s 309 & $8(2.59)$ & 0.00 & 0 & 0.32 & 1.29 & 0 & 0 & 0.65 & 0 & 0.32 \\
\hline$>3$ yrs & 178 & $7(3.93)$ & 1.12 & 0 & 0 & 2.81 & 0 & 0 & 0 & 0 & 0 \\
\hline
\end{tabular}

summer, rainy and autumn i.e. S-1 (Dec-Mar), S-2 (Apr-Jun), S-3 (Jul-Sep), S-4 (Oct-Nov) respectively; to assess mortality pattern in different age groups of male calves.

Reasons of mortality: The major reasons of mortality of Murrah buffalo males reported during the study period were 1 . Respiratory problems 2 . Digestive problems. 3. Liver problems 4. General debility 5. Cardiovascular problems 6. Parasitic problems 7. Toxemia 8. Uro-genital and 9. Miscellaneous. The problems considered under miscellaneous causes were anaemia, congenital anomalies, disposal of carcass, snake bite, peritonitis, babesiosis, actinomycosis, hypothermic shock, osteomyelitis and joint-ill.

Statistical analysis: The percent of animal disposed from the herd due to different reasons was calculated by proportion using descriptive statistics.

\section{Results and Discussion}

Mortality percent in different season and period of birth and mortality due to various problems in different age group of Murrah buffalo males are presented in Table-1 and 2. In winter season, respiratory problems were the main causes of mortality emphasizing the need of intensive care of new born calves in this season. Babcock et al. [10] studies on cohorts of U.S. commercial feedlot cattle have found that there was a seasonal pattern in culling and mortality risk in summer (MarchSep) than in winter (Nov-Feb). Main causes of mortality in age group 0-1 months were respiratory problems (6.61\%) and digestive problems $(5.05 \%)$ followed by general debility $(1.75 \%)$, miscellaneous $(1.65 \%)$, toxemia $(0.97 \%)$, liver problem $(0.87 \%)$, cardiovascular problem $(0.49 \%)$ and parasitic problem $(0.1 \%)$. The mortality pattern in $1-2 \mathrm{~m}$ age group also revealed that respiratory and digestive problems $(1.79 \%)$ were the main causes across different seasons and periods. An overall high mortality in younger age groups viz., $0-1 \mathrm{~m}, 1-2 \mathrm{~m}$, revealed that the calves in these age groups were more vulnerable to inclement weather conditions thereby suggesting the need for intensifying the care and management of young male buffalo calves during this period.

Shimizu and Nagatoma [11] reported that mortality of neonatal calves was attributed to conditions like diarrhoea and pneumonia. Didarkhah et al. [12] had found that pneumonia was the most common infectious disease that contributed to about $43 \%$ of disposal. Bangar et al. [13] reported that digestive (1.43\%) and nutritional diseases $(0.85 \%)$ were major causes of mortality of cattle whereas Waldner et al. [14] reported that $25 \%$ of deaths were due to nutritional factors. In 23 months age group, main causes of mortality were respiratory problems $(1.06 \%)$ followed by general debility $(0.76 \%)$, miscellaneous $(0.61 \%)$, digestive problems $(0.46 \%)$, toxemia $(0.30 \%)$, and liver problems $(0.30 \%)$. Khan et al. [15] reported that mortality rate was statistically influenced by age and found that mortality in buffalo calves was higher during the first three months.

In our study, main causes of mortality in age group 3-6 m were general debility $(1.57 \%)$ followed by respiratory and digestive problems $(1.22 \%)$, miscellaneous $(0.87 \%)$, liver and uro-genital problems $(0.17 \%)$. More number of cases of mortality was observed during the cold winter months of Dec-March and hot humid months of Jul-Sep. In 6-18 m age group, main causes of mortality were respiratory problems $(1.97 \%)$ followed by general debility (1.09\%) and liver problems $(1.09 \%)$, uro-genital $(0.66 \%)$, miscellaneous $(0.66 \%)$, digestive problems $(0.66 \%)$ and cardiovascular problems 
$(0.22 \%)$. Mortality could not reveal any definite trend across different seasons and period of birth. General debility $(1.29 \%)$ followed by toxemia $(0.65 \%)$, liver problems $(0.32 \%)$ and miscellaneous $(0.32 \%)$ were main causes of mortality in age group $18 \mathrm{~m}-3 \mathrm{yr}$ of age. In males above three years of age, general debility $(2.81 \%)$ followed by respiratory problems $(1.12 \%)$ were main causes of mortality.

In a study on morbidity and mortality rates in bovine in Himachal Pradesh, Chaudhary et al. [16] found highest mortality in calves $(21.53 \%)$ followed by young stocks $(9.35 \%)$ and adults $(4.73 \%)$. They also observed that calves had highest mortality due to poor management problems (16.09\%) followed by digestive diseases $(2.48 \%)$. Mortality was maximum in period-1 (1997-2000) and period-4 (2009-12) which could be due to high mortality in younger age group. Winter season was contraindicated for younger age group as highest mortality occurred during this season and thus more attention is required during this season. Respiratory and digestive problems were the main causes of death in younger age group while general debility was the main reason of mortality in adult animals (Table-2). Whereas still higher mortality during first month of their age was reported by Patil et al. [17] in Surti buffalo calves (33\%) and Pradhan and Panda [18] in Murrah buffalo calves (36.8\%). Sasidhar et al. [19] studied the reasons of culling of Murrah buffaloes and reported that debility and senility accounting for 20.18 \& 12.72 percent of disposal. Chhikara et al. [20] in Murrah buffaloes and Ahmad et al. [21] in Nili-Ravi buffaloes reported 8.19 and 22 percent culling due to health-related problems. Rathod [22] estimated mortality as $33.62 \%$ due to digestive disorders, $29.28 \%$ due to respiratory diseases and $17.48 \%$ due to miscellaneous reasons. Taraphder [23] analyzed mortality pattern in Murrah buffaloes and found that digestive problems accounted for $30.89 \%$, cardio-vascular problems for $26.02 \%$, respiratory $21.14 \%$, parasitic diseases $8.13 \%$, uro-genital $5.69 \%$ and miscellaneous $8.13 \%$ of the cases. Khan et al. [24] suggested that these health problems need to be evaluated in view of managemental practices followed and remedial measures to be adopted with particular attention towards the plane of nutrition. Blood et al. [25] found that calf mortality was associated with the type of housing, feeding, managemental practices, weather conditions, external and internal parasitic infestation and bacterial infections especially those causing septicemia and enteritis.

\section{Conclusions}

Intensive health care and management is the prerequisite for young male buffalo calves especially in rainy season and in winter months to minimize mortality due to respiratory and digestive problems which will facilitate maximizing intensity of selection among males born out of elite matings. Thus, we will be able to increase the availability of males with high genetic merit for progeny testing programmes.

\section{Authors' contributions}

AKG designed the work. PRS conducted study and analyzed the data. AP, SKD and AU helped in compilation of data. MB guided in classification of pattern of mortality. VK and SD helped in writing and revision of the manuscript. All authors read and approved the final manuscript.

\section{Acknowledgements}

The authors are thankful to the Head, DCB Division, Incharge, Cattle Yard and Incharge, ABRC of NDRI, India for providing necessary information. The authors also thankful to the Director, NDRI, India for financial assistance provided during the research work.

\section{Competing interests}

The authors declare that they have no competing interests.

\section{References}

1. FAO (2008) FAO statistical database. www.fao.org. Accessed on 12-02-2014.

2. Kumar, S., Gupta, J., Kumar, N., Dikshit, K., Navani, N., Jain, P. and Nagarajan, M. (2006) Genetic variation and relationships among eight Indian riverine buffalo breeds. Mol. Ecol., 15: 593-600.

3. FAO (2009) FAO statistical database. www.fao.org. Accessed on 12-02-2014.

4. 18th livestock census (2007) Department of Animal Husbandry, Dairying \& Fisheries, Ministry of Agriculture. India.

5. Resali, D.P. (2000) Recent trends in buffalo production in Nepal: A review, Buffalo News letter. Bulletin of the FAO Inter-Regional cooperative Research Network on Buffalo, Europe Near Estate, 14: 6-10.

6. Sangwan, M.L. (2012) Analysis of genetic diversity of Indian buffalo breeds by DNA markers. J. Buffalo Sci., 1: 91101.

7. Afzal, M., Javid, M. H. and Anjum, A. D. (1983) Calf mortality: Season Pattern, age distribution and causes of calf Mortality. Pak. Vet. J., 3 (1): 30-33.

8. Martin, S. W. and Wiggin. (1973) Perinatal diseases. Am. J. Vet. Res. 34, 1027. Quoted by Blood, D. C. 1994. Vet. Medicine, Eight Ed., ELBS, London. p107-112.

9. Dechow, C.D., Goodling, R.C. and Rhode, S.P. (2012) The effect of sire selection on cow mortality and early lactation culling in adverse and favorable cow survival environments. Prev. Vet. Med., 103: 228-233.

10. Babcock, A.H., Cernicchiaro, N., White, B.J., Dubnicka, S.R., Thomson, D.U., Ives, S.E., Scott, H.M., Milliken, G.A. and Renter, D.G. (2013) A multivariable assessment quantifying effects of cohort-level factors associated with combined mortality and culling risk in cohorts of U.S. commercial feedlot cattle. Prev. Vet. Med., 108: 38- 46.

11. Shimizu, T. and Nagatoma, H. (1978) Current status of calf diseases in Japan. Bull. Fac. Agri. Miyazaki Univ., 34: 329-336.

12. Didarkhah, M., Mesgaran, M.D., Abadi, E.I.K., Jamali, F. and Hosseini, S.M. (2013) Characterisation and Pattern of Culling in Holstein Dairy Cows in Torbat-E-Jam Area, Northeast of Iran. Journal of Agricultural Studies, 1(2): 151159

13. Bangar, Y., Khan, T.A., Dohare, A.K., Kolekar, D.V., Wakchaure, N. and Singh, B. (2013) Analysis of morbidity and mortality rates in cattle in Pune division of Maharashtra state. Vet. World, 6(8):512-515.

14. Waldner, C.L., Kennedy, R.I., Rosengren, L. and Clark, E.G. (2009) A field study of culling and mortality in beef cows 
from western Canada. Can. Vet. J., 50 (5): 491-499.

15. Khan, Z.U., Khan, S., Ahmad, N. and Raziq, A. (2007) Investigation of mortality incidence and managemental practices in buffalo calves at commercial dairy farms in Peshawar city. J. Agric. Bio. Sci., 2 (3): 16-22.

16. Chaudhary, J.K., Singh, B., Prasad, S. and Verma, M.R. (2013) Analysis of morbidity and mortality rates in bovine in Himachal Pradesh. Vet World, 6(9): 614-619.

17. Patil, N. A., Mallikarjunappa, S., Prasanna-Kumar, S. and Bhat, A. R. S. (1991) Comparative study on calf mortality in Jersey crossbred and Surti buffalo calves. Indian J. Dairy Sci., 44(8): 526-528.

18. Pardhan, B. and Panda G. M., (1994) Calving pattern and Mortality trends in Murrah buffaloes calves in Orisa. Indian Journal of Animal Production and Health, 10(4): 143-146.

19. Sasidhar, P.V.K., Rao Sudhakar, B. and Suresh, R.V. (2000) Caving pattern and lifetime performance attributes of buffaloes. Indian J. Dairy Sci., 53(3):239

20. Chhikara, B.S., Balaine, D.S., Chaudhary, S.R. and Chopra,
S.C. (1978) Performance levels and culling pattern in a Murrah buffalo herd. Indian J. Dairy Sci., 31(3):292-293.

21. Ahmad, Z., Berger, P.J. and Healey, M.H. (1992) Agespecific probability of culling under different culling criteria in Nili-Ravi buffalo. J. Dairy Sci., 75(6):1715-1724.

22. Rathore, B.S. (1998) An epidemiological study on buffalo morbidity and mortality based on four year observations on 18630 buffaloes maintained at 28 livestock farms in India. Indian J. Comp. Microbiol. Immunol. Infect. Dis., 19(1): 43-49.

23. Taraphder, S., Tomar, S.S. and Gupta, A.K. (2011) Studies on disposal pattern in an organized herd of Murrah buffalo. Online J.Vet. Res., 15 (1): 68-75.

24. Khan, H.M., Bhakat, M., Mohanty, T.K., Raina, V.S. and Gupta, A.K. (2011) Effect of non-genetic factors on reproductive disorders in Murrah buffaloes. Buffalo Bulletin, 30 (2): 120-126.

25. Blood, D. C., Radostits, O. M., Gay, C. C., Arundel, J. H., Ikede, B. O., Mekenzie, R. A. B. C. (1994) Veterinary Medicine Eighth Ed. ELBS, London. p425-498.

$* * * * * * * *$ 